\title{
Effects of Hypermetabolism on Ventilation and
}

\section{Chemosensitivity}

\author{
Clifford W. Zwillich, Steven A. Sahn, and John V. Weil, Cardiovascular \\ Pulmonary Research Laboratories and Division of Pulmonary Sciences, \\ Department of Medicine, University of Colorado Medical Center, \\ Denver, Colorado 80262
}

A B S T RACT Muscular exercise is associated with hypermetabolism and increased hypoxic ventilatory response (HVR). In order to dissociate mechanical and metabolic factors, the effect of hypermetabolism on hypoxic ventilatory response was evaluated at rest. Carbohydrate and protein feeding increases metabolic rate, and their effects on chemosensitivity, ventilation, and blood $\mathrm{pH}$ were evaluated in six normal subjects $2 \mathrm{~h}$ and $3 \mathrm{~h}$ after calorically equal test meals (1,000 cal).

After carbohydrate, base-line oxygen consumption $\left(\dot{\mathrm{VO}}_{2}\right)$ increased from $237 \pm 11.3 \mathrm{ml} / \mathrm{min}$ (SEM) to $302 \pm 19.4(P<0.001)$ and $303 \pm 18.5(P<0.001)$ at $2 \mathrm{~h}$ and $3 \mathrm{~h}$, respectively. Hypoxic ventilatory response, measured as shape parameter $A$, increased from a control of $144 \pm 11.8$ to $330 \pm 61.0(P<0.01)$ at $2 \mathrm{~h}$ and $286 \pm 57.0(P<0.05)$ at $3 \mathrm{~h}$. These changes were associated with a mild metabolic acidosis as $\mathrm{pH}$ decreased from a control of $7.402 \pm 0.004$ to $7.371 \pm 0.009$ ( $P$ $<0.005)$ at $2 \mathrm{~h}$ and $7.377 \pm 0.008(P<0.005)$ at $3 \mathrm{~h}$.

After protein, $\dot{\mathrm{VO}}_{2}$ increased from $241 \pm 6.7$ to $265 \pm 6.2$ $(P<0.02)$ and $270 \pm 5.4(P<0.001)$, an overall increase less than that which occurred after carbohydrate $(P$ $<0.01)$. Hypoxic ventilatory response increased from $105 \pm 14.5$ to $198 \pm 24.3(P<0.02)$ at $2 \mathrm{~h}$ and $219 \pm 17.3$ $(P<0.01)$ at $3 \mathrm{~h}$, which was not different from the increase with carbohydrate. After protein, no acidosis occurred. Thus, after protein, HVR increased despite the absence of a systemic acidosis.

We conclude that both carbohydrate and protein feedings are associated with resting hypermetabolism and increased HVR compared with the fasting state. For both meals, increased metabolic rate was correlated with increased hypoxic response.

Dr. Zwillich and Dr. Weil are the recipients of a National Institutes of Health Career Development Award.

Received for publication 5 April 1976 and in revised form 13 May 1977.

\section{INTRODUCTION}

Muscular exercise increases metabolism and produces large increases in the ventilatory response to hypoxia $(1,2)$. The nature of the stimulus which produces this increased ventilatory responsiveness to chemical stimuli remains unknown. At least two kinds of stimuli could be involved: mechanical, arising directly from the physical aspects of work, and chemical, related to increased metabolic activity. Studies in patients with low metabolic activity due to thyroid hormone deficiency (3) or due to semi-starvation (4) show marked decreases in hypoxic ventilatory response. Taken together with the findings in exercise, these studies suggest an association between metabolic activity and the sensitivity of the ventilatory control system. Accordingly, we sought to acutely increase metabolic activity in normal resting subjects to determine whether this would have a significant effect on ventilatory control. Feeding a meal causes an increase in metabolic rate $(5,6)$, and this effect was utilized in this study to measure the influence of increased metabolic rate on chemosensitivity.

\section{METHODS}

Study protocol. Six normal male subjects between the ages of 28 and $40 \mathrm{yr}$ of age were studied after informed consent was obtained. The subjects were fasted overnight for $12 \mathrm{~h}$. The next morning after a $1-\mathrm{h}$ basal period in the recumbent position, base-line oxygen consumption $\left(\dot{V}_{\mathbf{O}_{2}}\right)_{,}{ }^{1}$ carbon dioxide production $\left(\dot{\mathrm{V}} \mathrm{CO}_{2}\right)$, resting ventilation $\left(\dot{\mathrm{V}}_{\mathrm{E}}\right)$, heart rate (HR), blood pressure, hematocrit, serum electrolytes, and arterialized venous blood for $\mathrm{pH}$ and $\mathrm{PCO}_{2}$ were measured. Ventilatory responses to hypoxia were then meas-

\footnotetext{
${ }^{1}$ Abbreviations used in this paper: BTPS, body temperature and pressure, saturated with water vapor; HR, heart rate; $\mathbf{P A}_{\mathrm{O}_{2}}$, end-tidal oxygen tension; STPD, standard temperature and pressure, dry; $\mathrm{VCO}_{2}$, carbon dioxide production; $\dot{\mathrm{V}}_{\mathrm{E}}$, resting ventilation; $\dot{\mathrm{V}}_{\mathrm{O}_{2}}$, oxygen consumption; $\dot{\mathrm{V}}_{\mathrm{O}}$, asymptote for ventilation derived by extrapolation.
} 
ured in duplicate and averaged. The response to hypercapnia was measured once. The meal was then administered in a double-blind protocol through a nasogastric tube. Test meals consisted of $1,000 \mathrm{ml}$ of either water, glucose solution containing 1,000 calories, or egg albumin solution again containing 1,000 calories. We only gave one meal per day, and the order of the meals was random. The application of nasal and oral lidocaine and a blindfold were effective in preventing subjects from detecting which meal had been given.

All variables were again measured at 2 and $3 \mathrm{~h}$ after the meal. Repeat studies were done at 1 -wk intervals. To eliminate diurnal effects, all studies were performed at the same time of day.

Measurements. Metabolic rate expressed as oxygen consumption $\left(\dot{\mathrm{V}}_{2}\right)$ and carbon dioxide production $\left(\dot{\mathrm{VCO}}_{2}\right)$ were measured from expired air collected in a bag over a 6-min period. During the 6-min collection, mean end-tidal $\mathrm{CO}_{2}$ $\left(\mathrm{P}_{\mathrm{ET}} \mathrm{CO}_{2}\right)$ was determined. Gas concentrations and volumes were measured by the Scholander technique and Tissot apparatus, respectively. All gas volumes were corrected to body temperature, ambient pressure, and saturated (BTPS), except for $\mathrm{VO}_{2}$ and $\mathbf{V C O}_{2}$, which were expressed STPD.

Ventilatory responses were determined with the subject reclining in a semi-darkened room, and television was used as a visual and auditory distraction. Hypoxic ventilatory response was measured during progressive isocapnic hypoxia (7). Briefly, the subject breathed through a Rudolph respiratory valve (Warren E. Collins, Inc., Braintree, Mass.) from which gases were continuously sampled by an infrared $\mathrm{CO}_{2}$ analyzer (Beckman LB-1, Beckman Instruments Inc., Palo Alto, Calif.) and by a fuel cell oxygen analyzer (8). The ventilatory flow was measured with a hot film anometer (Thermal Systems, Mfg. Co., Merriam, Kan.), which was calibrated against a Tissot spirometer. Oxygen, carbon dioxide, and flow signals were fed into an online Nova computer (Data General Corp., Southboro, Mass.), the data emerging as continuous real-time oscilloscopic plots of end-tidal oxygen tension, end-tidal carbon dioxide tension, and minute ventilation. The endtidal oxygen plot was used to guide the manual addition of nitrogen to the inspired gas $\left(30 \% \quad \mathrm{O}_{2}\right.$ remainder $\mathrm{N}_{2}$ ) so as to produce a gradual fall in end-tidal oxygen tension $\left(\mathrm{P}_{\mathrm{A}_{2}}\right)$ from 130 to $40 \mathrm{~mm} \mathrm{Hg}$ over a 7 - to $8-\mathrm{min}$ period. Output from a carbon dioxide analyzer was also displayed on an oscilloscope and used to guide the manual addition of $100 \%$ carbon dioxide to the inspired gas in amounts sufficient to prevent hypocapnia. End-tidal carbon dioxide tension was controlled within $1 \mathrm{~mm} \mathrm{Hg}$ with this technique (7) and was maintained at the $\mathrm{PA}_{\mathrm{CO}_{2}}$ determined during the 6-min collection. The plots of ventilation in relation to $\mathrm{PA}_{\mathrm{O}_{2}}$ are hyperbolic. To compare curves, a simple empiric equation is used relating ventilation to alveolar $\mathrm{PO}_{2}$ as follows: $\dot{\mathrm{V}}_{\mathrm{E}}=\dot{\mathrm{V}}_{0}+\mathbf{A} /\left(\mathrm{PA}_{\mathrm{O}_{2}}-32\right)$ where $\dot{\mathrm{V}}_{\mathrm{E}}$ and $\mathrm{PA}_{\mathrm{O}_{2}}$ are minute ventilation in liters per min $B T P S$ and $P_{A_{O_{2}}}$ is alveolar oxygen tension in $\mathrm{mm} \mathrm{Hg}$, respectively. Parameter $\dot{\mathrm{V}}_{0}$ is the asymptote for ventilation obtained by extrapolation, and parameter A determines the shape of the curve such that the higher the value for $A$, the greater the hypoxic ventilatory response. In practice, values of these parameters utilize the fact that the relationship between ventilation and $1 /\left(\mathbf{P A}_{\mathbf{O}_{2}}-32\right)$ is linear, with a slope of $A$ and an intercept of $\dot{V}_{0}$. Slope and intercept $\left(A\right.$ and $\dot{V}_{0}$ ) are evaluated with the least-squares method (9). The parameter A describes the hypoxic ventilatory response curve such that the ventilation at any given $\mathrm{PA}_{\mathrm{O}_{2}}$ during a study is within $4 \%$ of the measured ventilation (7).

A second method was used to evaluate hypoxic ventilatory response. It quantifies the increase in $\dot{V}_{E}$ from room air breathing to the $\dot{\mathrm{V}}_{\mathrm{E}}$ at $\mathrm{PA}_{\mathrm{O}_{2}}=40 \mathrm{~mm} \mathrm{Hg}\left(\Delta \dot{\mathrm{V}}_{40}\right)$.

The hypercapnic ventilatory response was measured using a rebreathing method similar to that described by Read (10), in which a 5-liter rebreathing circuit was filled with $40 \%$ oxygen in nitrogen. Data were collected when inspired $\mathrm{PCO}_{2}$ approached $4 \%$. The ventilatory responses were related to alveolar $\mathrm{PCO}_{2}$ by the equation $\dot{\mathrm{V}}_{\mathrm{E}}=\mathrm{S}\left(\mathrm{PA}_{\mathrm{CO}_{2}}-\mathrm{B}\right)$, where $B$ is the extrapolated intercept on the abscissa and $S$ is the slope
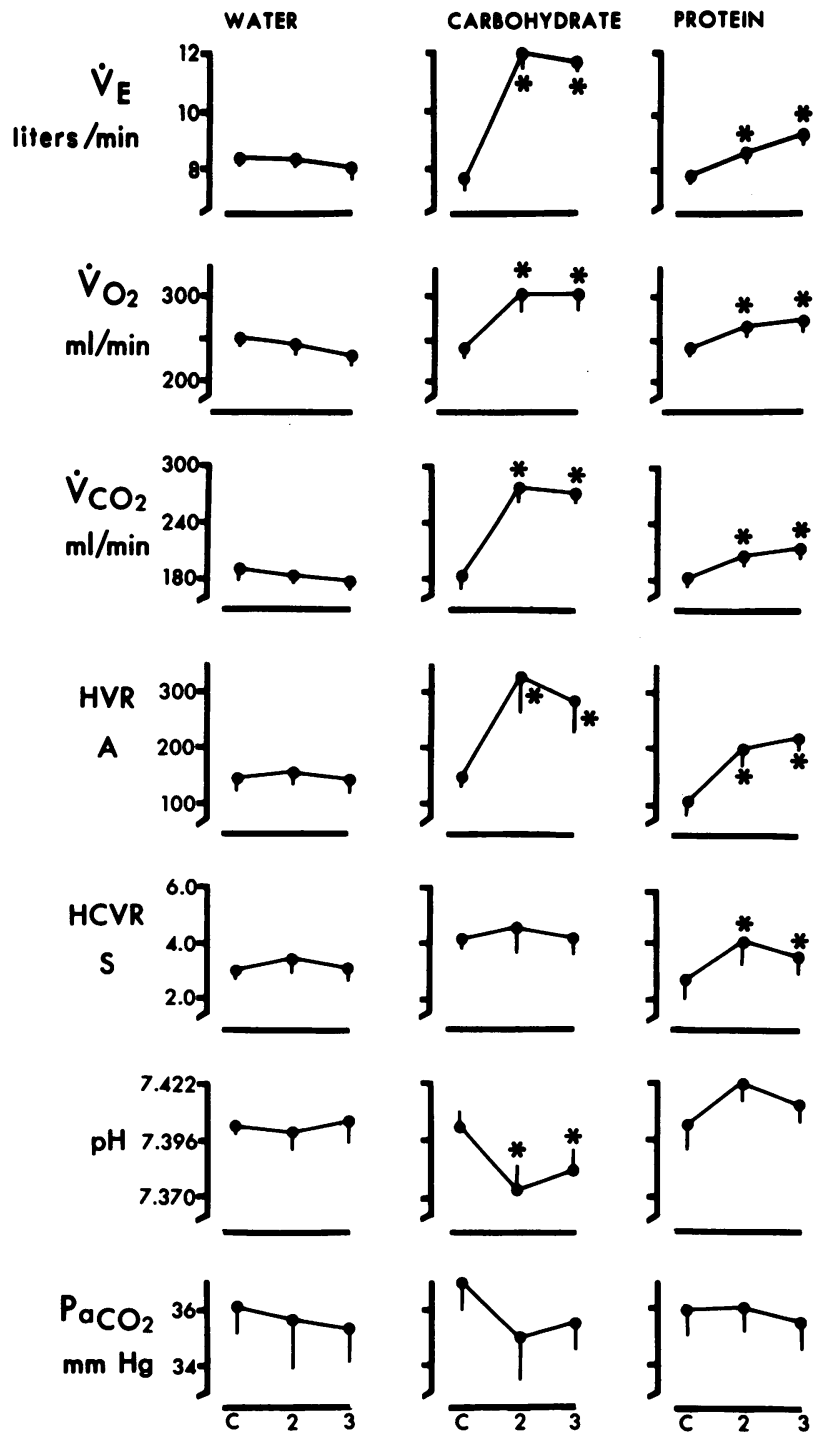

HOURS AFTER EACH MEAL

Figure 1 Effects of water (placebo), carbohydrate, and protein on respiratory and metabolic variables. No significant changes occurred after placebo. After carbohydrate, ventilation $\left(\dot{\mathrm{V}}_{\mathrm{E}}\right)$, metabolic rate $\left(\mathrm{V}_{2}, \dot{\mathrm{V}} \mathrm{CO}_{2}\right)$, and hypoxic ventilatory response (HVR) increased, while $\mathrm{pH}$ decreased. After protein, ventilation, metabolic rate, and both hypoxic and hypercapnic ventilatory response increased, while no significant alteration in $\mathrm{pH}$ occurred. The asterisk $\left({ }^{*}\right)$ signifies differences significantly different $(P<0.05)$ from control. 
of the response line. Responses are linear with this method. Normal values obtained with this method (11) are similar to those reported by Read (10) and others $(12,13)$.

Heart rate (HR) was measured continuously throughout all studies. Following the method of Forster et al. (14), arterial $\mathbf{p H}$ and arterial carbon dioxide tensions were measured with appropriate electrodes from arterialized venous blood. The adequacy of skin warming was assured by constant skin temperature measurement (thermocouple, Yellow Springs Instrument Company, Inc., Yellow Springs, Ohio). Blood pressure measurements were made with a standard blood pressure cuff. Serum potassium, sodium, chloride, and bicarbonate concentrations were measured by AutoAnalyzer (Technicon Instruments, Inc., Tarrytown, N. Y.). Hematocrit was measured in duplicate from unoccluded venous blood. Body temperature was measured with a calibrated rectal thermocouple.

The analysis of variance and Scheffé's test (9) were used to determine if the variables measured after the meals were different from the controls or placebo meal.

\section{RESULTS}

Fig. 1 and Table I show the effects of placebo, carbohydrate, and protein meals on the variables measured. Placebo had no significant effects on the variables except for a slight decrease in serum sodium and potassium concentration, which probably reflected dilution (16). Heart rate increased $15 \pm 3.8$ beats per minute at $2 \mathrm{~h}(P<0.01)$ and $15 \pm 5.9(P$ $<0.01)$ at 3 hours after the carbohydrate meal, but was not significantly affected by protein. Systolic blood pressure rose to a small but statistically significant degree $3 \mathrm{~h}$ after the carbohydrate meal, but was not significantly affected by protein. Diastolic blood pressure was unchanged in all groups. Resting minute ventilation increased at 2 and $3 \mathrm{~h}$ after both carbohydrate and protein meals. This increase was greater with carbohydrate $(P<0.01)$. Both oxygen consumption and carbon dioxide production were significantly increased after the carbohydrate-rich ( $P$ $<0.001)$ and protein-rich meal $(P<0.005)$. These increases were greater after the carbohydrate than the protein $(P<0.025)$. The increases in $\dot{\mathrm{V}}_{\mathrm{E}}, \dot{\mathrm{V}}_{2}$, and $\dot{\mathrm{V}} \mathrm{CO}_{2}$ were also significant $(P<0.05)$ when compared with measurements after the placebo meal.

TABLE I

Serial Measurements before and after

\begin{tabular}{|c|c|c|c|c|c|c|c|c|c|c|}
\hline Meal & $\dot{\mathbf{V}}_{\mathbf{E}}$ & $\dot{\mathrm{V}}_{\mathrm{O}_{2}}$ & $\dot{\mathrm{v}}_{\mathrm{CO}_{2}}$ & $\begin{array}{l}\text { Hypoxic } \\
\text { ventilatory } \\
\text { response } \\
\text { (A) }\end{array}$ & $\dot{v}_{0}$ & $\begin{array}{l}\text { Hypercapnic } \\
\text { ventilatory } \\
\text { response } \\
\text { (S) }\end{array}$ & $\begin{array}{l}\text { Intercept } \\
\text { (B) }\end{array}$ & $\begin{array}{c}\text { Heart } \\
\text { rate }\end{array}$ & $\begin{array}{l}\text { Temper- } \\
\text { ature }\end{array}$ & $\mathrm{pH}^{*}$ \\
\hline & liters/min & $\mathrm{ml} / \mathrm{min}$ & $\mathrm{ml} / \mathrm{min}$ & & & $l / m i n / m m ~ H g$ & $m m \mathrm{Hg}$ & beats/min & ${ }^{\circ} \mathrm{C}$ & \\
\hline \multicolumn{11}{|l|}{ Water } \\
\hline Control & 8.4 & 255 & 189 & 146 & 4.9 & 3.1 & 33.5 & 60 & 36.8 & 7.400 \\
\hline SEM & 0.26 & 5.2 & 7.2 & 12.9 & 0.36 & 0.31 & 1.2 & 3.4 & 0.21 & 0.007 \\
\hline $2 \mathrm{~h}$ & 8.3 & 243 & 184 & 154 & 5.2 & 3.5 & 33.8 & 61 & 36.8 & 7.398 \\
\hline SEM & 0.19 & 6.6 & 6.5 & 12.7 & 0.35 & 0.55 & 0.78 & 2.9 & 0.24 & 0.005 \\
\hline $3 \mathrm{~h}$ & 8.0 & 229 & 178 & 142 & 5.3 & 3.1 & 34.7 & 60 & 36.8 & 7.404 \\
\hline SEM & 0.42 & 6.3 & 7.5 & 20.3 & 0.66 & 0.29 & 0.68 & 3.6 & 0.27 & 0.006 \\
\hline \multicolumn{11}{|c|}{ Carbohydrate } \\
\hline Control & 7.7 & 237 & 182 & 144 & 4.7 & 4.2 & 34.7 & 58 & 36.9 & 7.402 \\
\hline SEM & 0.47 & 11.3 & 14.8 & 11.8 & 0.92 & 0.48 & 1.29 & 3.8 & 0.13 & 0.004 \\
\hline $2 \mathrm{~h}$ & $11.8 \S$ & $302 \S$ & $281 \S$ & $330 \S$ & 5.3 & 4.6 & 33.5 & $73 \S$ & 37.1 & $7.371 \S$ \\
\hline SEM & 0.54 & 19.4 & 14.7 & 60.9 & 0.84 & 0.88 & 1.24 & 5.1 & 0.14 & 0.009 \\
\hline $3 \mathrm{~h}$ & $11.4 \S$ & $303 \S$ & $276 \S$ & $286 \ddagger$ & 5.7 & 4.3 & 32.8 & $73 \S$ & 37.1 & $7.377 \S$ \\
\hline SEM & 0.25 & 18.5 & 10.6 & 56.9 & 0.86 & 0.58 & 1.15 & 5.9 & 0.16 & 0.008 \\
\hline \multicolumn{11}{|l|}{ Protein } \\
\hline Control & 7.8 & 241 & 183 & 105 & 5.7 & 2.8 & 32.3 & 65 & 36.9 & 7.405 \\
\hline SEM & 0.31 & 6.7 & 10.6 & 14.5 & 0.40 & 0.67 & 1.50 & 4.1 & 0.17 & 0.009 \\
\hline $2 \mathrm{~h}$ & $8.6 \ddagger$ & $265 \S$ & $202 \ddagger$ & $198 \ddagger$ & 4.5 & $4.1 \S$ & $35.6 \ddagger$ & 66 & 36.9 & 7.420 \\
\hline SEM & 0.26 & 6.2 & 8.1 & 24.3 & 0.55 & 0.80 & 0.98 & 4.2 & 0.22 & 0.005 \\
\hline $3 \mathrm{~h}$ & $9.2 \S$ & $270 \S$ & $213 \S$ & $219 \S$ & 4.1 & $3.6 \ddagger$ & 33.4 & 67 & 36.9 & 7.412 \\
\hline SEM & 0.20 & 5.4 & 8.0 & 17.3 & 0.59 & 0.62 & 0.59 & 4.5 & 0.21 & 0.006 \\
\hline
\end{tabular}

* Normal values at $1,600 \mathrm{~m}\left(\mathrm{pH}=7.420 \pm 0.004, \mathrm{~Pa}_{\mathrm{CO}_{2}}=35.6 \pm 0.6 \mathrm{~mm} \mathrm{Hg}\right)(15)$.

† Signifies value different from control $(P<0.05)$.

$\$$ Signifies value different from control $(P<0.01)$. 
Hypoxic ventilatory response, measured as the shape parameter A, increased consistently and significantly after the carbohydrate meal from a control value of $144 \pm 11.8$ to a 2 -h value of $330 \pm 16.0(P<0.01)$ and $286 \pm 56.9(P<0.05)$ at $3 \mathrm{~h}$ (Fig. 2). After protein, hypoxic response was again increased in all subjects from a control value of $105 \pm 14.5$ to $198 \pm 24.3$ ( $P$ $<0.025)$ at $2 \mathrm{~h}$ and $219 \pm 17.3$ at $3 \mathrm{~h}(P<0.01)$. The increase in hypoxic response after carbohydrate was not significantly different than after protein. The intercept $\dot{V}_{0}$ was not significantly altered by any of the meals. The increases in hypoxic ventilatory responses after carbohydrate and protein were also significant $(P<0.05)$ when compared with changes which occurred after the placebo meal. There was no significant difference between the control hypoxic responses measured before each meal. These increases in hypoxic ventilatory response were also evident when the increment of ventilation from room air breathing to a $\mathrm{PA}_{\mathrm{O}_{2}}=40 \mathrm{~mm} \mathrm{Hg}\left(\Delta \dot{\mathrm{V}}_{40}\right)$ was quantified. With placebo, the control $\Delta \dot{\mathrm{V}}_{40}$ of $14.8 \pm 1.63$ liters/min was not significantly different from the 2 -h value of 16.2 \pm 1.57 or the 3 -h value of $15.1 \pm 2.25$. However, with carbohydrate, $\Delta \dot{\mathrm{V}}_{40}$ increased significantly $(P<0.01)$ from a control value of $14.9 \pm 1.11$ liters $/ \mathrm{min}$ to 34.8 \pm 6.70 and $30.1 \pm 6.41$ at 2 and $3 \mathrm{~h}$. Protein was also associated with an increase from control of $11.1 \pm 1.82$ liters/min to $20.6 \pm 2.82$ and $22.3 \pm 1.80$ at 2 and $3 \mathrm{~h}$ $(P<0.04)$. The mean control $\Delta \dot{\mathrm{V}}_{40}$ measured before each meal were not statistically different.

The relationship between increased $\dot{\mathrm{VO}}_{2}$ and hypoxic ventilatory response is shown in Fig. 3. A positive slope of $\mathrm{VO}_{2}$ versus hypoxic response is seen after all meals except for subject 4 , who had a slightly negative slope only after protein. This relationship was significant for both carbohydrate and protein ( $P$ $<0.03$ ).

The hypercapnic ventilatory response was unaffected by the carbohydrate meal but rose signifcantly after protein from a control value of $2.8 \pm 0.67$ liters/min per $\mathrm{mm} \mathrm{Hg}$ to $4.0 \pm 0.80(P<0.005)$ at $2 \mathrm{~h}$ and 3.6 $\pm 0.62(P<0.05)$ at $3 \mathrm{~h}$. The intercept $B$ was

Water, Carbohydrate, and Protein Meals

\begin{tabular}{|c|c|c|c|c|c|c|c|c|c|c|}
\hline \multirow[b]{2}{*}{$\mathbf{P}_{\mathrm{con}_{2}}$} & \multirow[b]{2}{*}{ HCT } & \multicolumn{2}{|c|}{ Blood pressure } & \multirow[b]{2}{*}{$\mathrm{Na}^{+}$} & \multirow[b]{2}{*}{$\mathbf{K}^{+}$} & \multirow[b]{2}{*}{$\mathrm{Cl}^{-}$} & \multirow[b]{2}{*}{$\mathrm{HCO}_{3}^{-}$} & \multirow{2}{*}{$\begin{array}{c}\text { Total } \\
\text { protein }\end{array}$} & \multirow[b]{2}{*}{ Albumin } & \multirow[b]{2}{*}{$\mathbf{R Q}$} \\
\hline & & Systolic & Diastolic & & & & & & & \\
\hline$m m \mathrm{Hg}$ & & & & meq/liter & meq/liter & meq/liter & meq/liter & g/100- & g/100- & \\
\hline $\begin{array}{c}36.1 \\
0.89\end{array}$ & $\begin{array}{r}41.8 \\
0.9\end{array}$ & $\begin{array}{r}115 \\
4.3\end{array}$ & $\begin{array}{l}74 \\
2.7\end{array}$ & $\begin{array}{r}137 \\
0.7\end{array}$ & $\begin{array}{l}3.9 \\
0.08\end{array}$ & $\begin{array}{l}105 \\
1.2\end{array}$ & $\begin{array}{c}23.1 \\
0.13\end{array}$ & $\begin{array}{l}6.3 \\
.0 .08\end{array}$ & $\begin{array}{l}4.1 \\
0.09\end{array}$ & $\begin{array}{l}0.74 \\
0.002\end{array}$ \\
\hline $\begin{array}{c}35.7 \\
1.68\end{array}$ & $\begin{array}{r}41.8 \\
1.4\end{array}$ & $\begin{array}{l}115 \\
3.1\end{array}$ & $\begin{array}{l}78 \\
2.1\end{array}$ & $\begin{array}{r}135 \ddagger \\
0.9\end{array}$ & $\begin{array}{l}3.7 \ddagger \\
0.06\end{array}$ & $\begin{array}{r}104 \\
1.0\end{array}$ & $\begin{array}{c}23.1 \\
0.61\end{array}$ & $\begin{array}{l}6.2 \\
0.10\end{array}$ & $\begin{array}{l}4.2 \\
0.06\end{array}$ & $\begin{array}{l}0.76 \\
0.002\end{array}$ \\
\hline $\begin{array}{c}35.4 \\
1.21\end{array}$ & $\begin{array}{r}42.8 \\
0.9\end{array}$ & $\begin{array}{l}118 \\
2.8\end{array}$ & $\begin{array}{l}77 \\
2.3\end{array}$ & $\begin{array}{l}136 \\
0.7\end{array}$ & $\begin{array}{l}3.7 \ddagger \\
0.06\end{array}$ & $\begin{array}{r}106 \\
1.0\end{array}$ & $\begin{array}{c}24.0 \\
0.51\end{array}$ & $\begin{array}{l}6.3 \\
0.10\end{array}$ & $\begin{array}{l}4.3 \\
0.06\end{array}$ & $\begin{array}{l}0.78 \\
0.002\end{array}$ \\
\hline $\begin{array}{c}36.8 \\
0.98\end{array}$ & $\begin{array}{c}43.0 \\
0.58\end{array}$ & $\begin{array}{r}118 \\
4.8\end{array}$ & $\begin{array}{l}78 \\
2.0\end{array}$ & $\begin{array}{r}138 \\
0.72\end{array}$ & $\begin{array}{l}4.0 \\
0.09\end{array}$ & $\begin{array}{l}105 \\
0.7\end{array}$ & $\begin{array}{c}24.8 \\
1.02\end{array}$ & $\begin{array}{l}6.2 \\
0.05\end{array}$ & $\begin{array}{l}4.2 \\
0.12\end{array}$ & $\begin{array}{l}0.77 \\
0.004\end{array}$ \\
\hline $\begin{array}{c}35.0 \\
1.43\end{array}$ & $\begin{array}{c}44.0 \\
0.68\end{array}$ & $\begin{array}{r}122 \\
4.2\end{array}$ & $\begin{array}{l}75 \\
2.5\end{array}$ & $\begin{array}{r}138 \\
0.84\end{array}$ & $\begin{array}{l}3.4 \S \\
0.07\end{array}$ & $\begin{array}{r}106 \\
0.8\end{array}$ & $\begin{array}{r}22.3 \ddagger \\
1.49\end{array}$ & $\begin{array}{l}6.3 \\
0.08\end{array}$ & $\begin{array}{l}4.4 \\
0.13\end{array}$ & $\begin{array}{l}0.93 \S \\
0.002\end{array}$ \\
\hline $\begin{array}{c}35.5 \\
1.01\end{array}$ & $\begin{array}{c}43.7 \\
0.62\end{array}$ & $\begin{array}{r}126 \ddagger \\
4.9\end{array}$ & $\begin{array}{l}73 \\
2.5\end{array}$ & $\begin{array}{r}138 \\
0.72\end{array}$ & $\begin{array}{l}3.4 \oint \\
0.06\end{array}$ & $\begin{array}{r}106 \\
1.3\end{array}$ & $\begin{array}{r}22.3 \ddagger \\
1.05\end{array}$ & $\begin{array}{l}6.2 \\
0.10\end{array}$ & $\begin{array}{l}4.3 \\
0.12\end{array}$ & $\begin{array}{l}0.92 \ddagger \\
0.002\end{array}$ \\
\hline $\begin{array}{c}36.0 \\
0.97\end{array}$ & $\begin{array}{r}44.4 \\
1.3\end{array}$ & $\begin{array}{r}113 \\
4.1\end{array}$ & $\begin{array}{l}76 \\
2.6\end{array}$ & $\begin{array}{r}139 \\
1.1\end{array}$ & $\begin{array}{l}3.8 \\
0.18\end{array}$ & $\begin{array}{r}105 \\
0.48\end{array}$ & $\begin{array}{c}22.9 \\
1.45\end{array}$ & $\begin{array}{l}6.1 \\
0.17\end{array}$ & $\begin{array}{l}4.2 \\
0.05\end{array}$ & $\begin{array}{l}0.76 \\
0.004\end{array}$ \\
\hline $\begin{array}{c}36.1 \\
1.00\end{array}$ & $\begin{array}{r}43.8 \\
1.4\end{array}$ & $\begin{array}{l}116 \\
3.7\end{array}$ & $\begin{array}{l}78 \\
2.8\end{array}$ & $\begin{array}{r}139 \\
1.3\end{array}$ & $\begin{array}{l}4.5 \oint \\
0.04\end{array}$ & $\begin{array}{r}103 \\
1.1\end{array}$ & $\begin{array}{r}24.7 \\
1.31\end{array}$ & $\begin{array}{l}6.2 \\
0.12\end{array}$ & $\begin{array}{l}4.3 \\
0.05\end{array}$ & $\begin{array}{l}0.76 \\
0.002\end{array}$ \\
\hline $\begin{array}{c}35.5 \\
1.19\end{array}$ & $\begin{array}{r}44.0 \\
1.6\end{array}$ & $\begin{array}{c}114 \\
3.0\end{array}$ & $\begin{array}{l}75 \\
2.1\end{array}$ & $\begin{array}{r}138 \\
1.1\end{array}$ & $\begin{array}{l}4.1 \\
0.12\end{array}$ & $\begin{array}{l}105 \\
0.71\end{array}$ & $\begin{array}{c}23.3 \\
1.21\end{array}$ & $\begin{array}{l}6.2 \\
0.12\end{array}$ & $\begin{array}{l}4.3 \\
0.07\end{array}$ & $\begin{array}{l}0.79 \\
0.002\end{array}$ \\
\hline
\end{tabular}



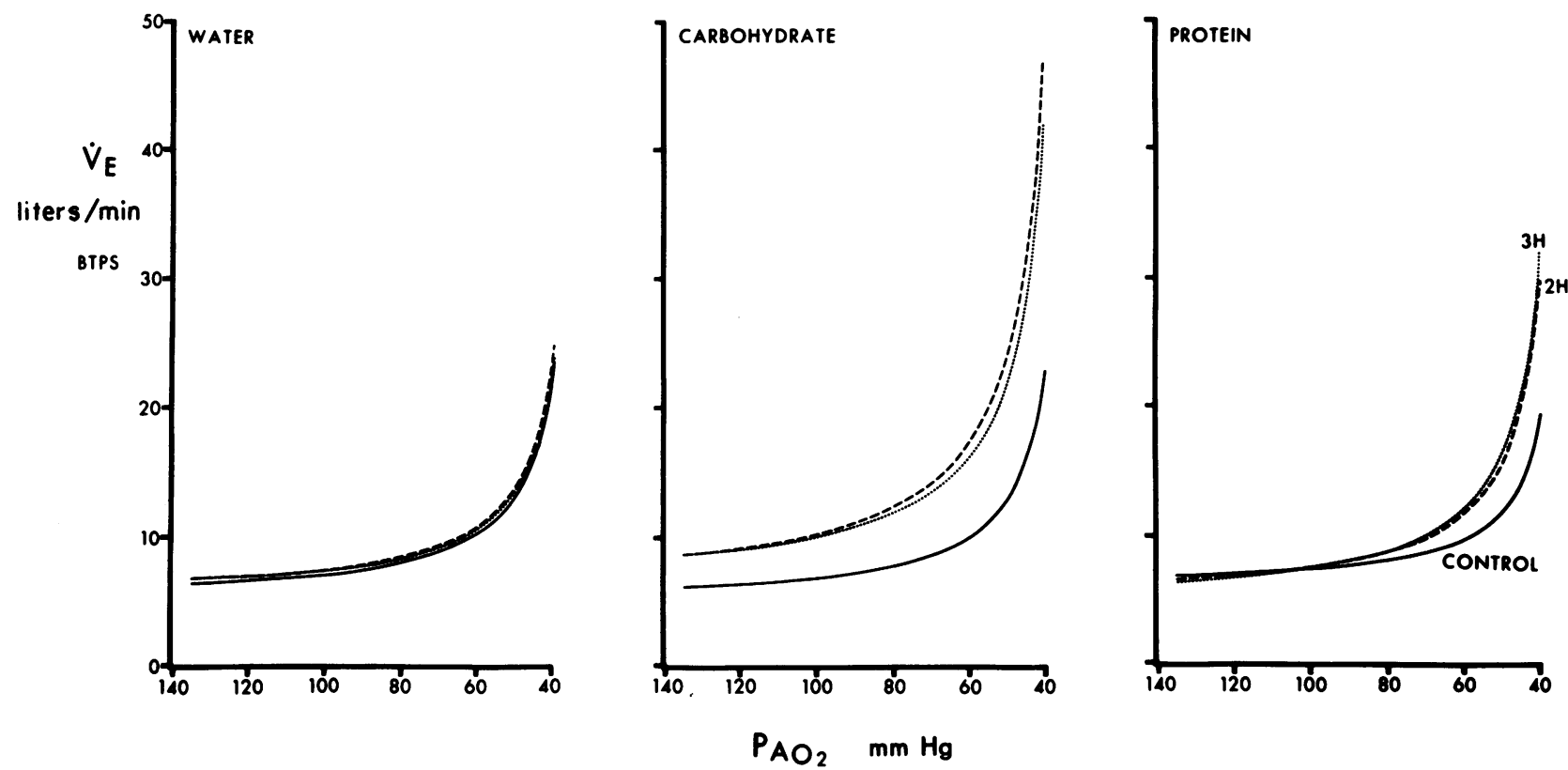

FIGURE 2 Effects of placebo (water), carbohydrate, and protein meals on hypoxic ventilatory response in six subjects. A consistent increase in hypoxic response was found 2 and $3 \mathrm{~h}$ after both carbohydrate and protein. No changes occurred after placebo.

increased only after protein from $32.3 \pm 1.5 \mathrm{~mm} \mathrm{Hg}$ to $35.6 \pm 0.98(P<0.025)$ at $2 \mathrm{~h}$.

Arterialized venous $\mathrm{pH}$ fell after the carbohydrate

HVR
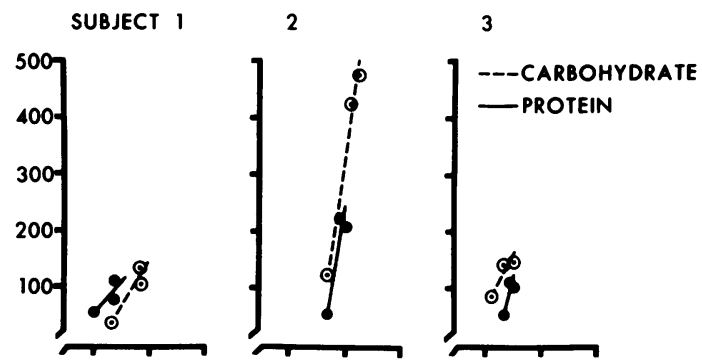

$A / m^{2}$

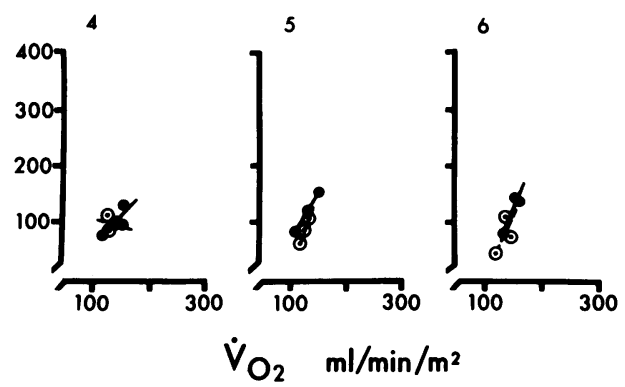

FIGURE 3 The relationship between changes in metabolic rate $\left(\mathrm{VO}_{2}\right)$ and hypoxic ventilatory response (HVR) after carbohydrate and protein meals. After carbohydrate, increases in $\mathrm{VO}_{2}$ were always associated with increases in HVR $(P<0.02)$. After protein, a similar relationship was found in five of six subjects $(P<0.03)$. meal from $7.402 \pm 0.005$ to $7.371 \pm 0.009(P<0.005)$ at $2 \mathrm{~h}$ and $7.377 \pm 0.008(P<0.005)$ at $3 \mathrm{~h}$. After the protein and placebo meal, $\mathrm{pH}$ was slightly but nonsignificantly altered. Small nonsignificant alterations in $\mathrm{PCO}_{2}$, hematocrit, total protein, and albumin were present after protein and carbohydrate.

Neither the carbohydrate nor the protein meal significantly affected serum sodium. After carbohydrate, serum potassium fell from a control value of 3.95 $\pm 0.09 \mathrm{meq} / \mathrm{liter}$ to $3.37 \pm 0.067(P<0.001)$ at $2 \mathrm{~h}$ and remained depressed at $3 \mathrm{~h}$. In contrast to carbohydrate, protein increased serum potassium from $3.75 \mathrm{meq} / \mathrm{liter}$ \pm 0.18 in control period to $4.48 \pm 0.04(P<0.001)$ but had returned to a value similar to control $(P=N S)$ by $3 \mathrm{~h}$. Plasma bicarbonate concentrations decreased after the carbohydrate meal; it fell from a control value of $24.8 \pm 1.02 \mathrm{meq} / \mathrm{liter}$ to $22.3 \pm 1.49(P<0.025)$ at $2 \mathrm{~h}$ and $22.3 \pm 1.05(P<0.025)$ at $3 \mathrm{~h}$. After the protein meal, plasma bicarbonate rose from $22.9 \pm 0.45$ to $24.7 \pm 1.31(P<0.025)$ at $2 \mathrm{~h}$, but the value of 23.3 \pm 1.21 at $3 \mathrm{~h}$ was not significantly different from control.

\section{DISCUSSION}

This study shows that resting ventilation and hypoxic ventilatory response increase after carbohydrate or protein meals and these changes were closely associated with increases in metabolic rate. These increases 
in resting ventilation and metabolic rate resemble those found by Saltzman and Salzano (6) after a similar carbohydrate meal. A close association between these alterations has been found in a number of other conditions; in thyrotoxicosis (17), hyperthermia (18), dinitrophenol administration (19), and muscular exercise, metabolism, and ventilation are increased. Conversely, when metabolic rate is decreased, as in myxedema (3) and semi-starvation (4), resting minute ventilation is decreased.

Few studies have evaluated the effects of alteration of metabolic rate on ventilatory responses to chemical stimuli. Vejby-Christensen (20) has shown recently that raising body temperature raises metabolic rate and hypercapnic ventilatory response. Similarly, Engel and Ritchie (21) studied hypermetabolic patients with thyrotoxicosis and also found an increase in hypercapnic ventilatory responses. Neither of these studies examined the effects of increased metabolism on hypoxic ventilatory response. Edelman et al. (22) have reported that hypoxic ventilatory response was increased in a patient with an elevated metabolic rate at rest due to the Luft's syndrome ("loose coupling" of oxidation to phosphorylation). In that patient, no increase in hypercapnic ventilatory response was found. This augmentation of hypoxic but not hypercapnic response resembles the pattern found in the present study after the feeding of carbohydrate. Previous studies have reported that exercise was associated with increases in hypoxic ventilatory responses $(1,2)$. It was not clear from those studies, however, whether the augmentation in chemosensitivity was due to the mechanical or metabolic consequences of exercise.

The finding that ventilation and hypoxic ventilatory response are augmented with increased metabolism may contribute to the understanding of the hyperpnea and increased chemosensitivity of exercise. However, the effects of limb motion on carotid body sensitivity to hypoxia may also be important; Biscoe and Purves (23) showed that this enhanced both carotid body neural output and minute ventilation, an effect abolished by cutting nerves from the extremity.

The present study does not define the mechanism whereby hypoxic ventilatory response is increased during hypermetabolism. Carotid body sensitivity to hypoxia might be increased during hypermetabolism by activation of peripheral "metabolic sensors" described by Ramsay (24). Another possible explanation for increased ventilation and hypoxic response is the decrease in arterial $\mathrm{pH}$ after a carbohydrate meal found by us and others (6). Both of these effects are known to accompany acidosis (25). However, metabolic acidosis does not seem to be a requirement for the postprandial augmentation of resting ventilation and chemosensitivity, since both were significantly in- creased after the protein meal when $\mathrm{pH}$ was unchanged.

Wasserman et al. (26) have shown that ventilation immediately increases when bulk carbon dioxide delivery to the lung is enhanced either by increasing cardiac output or by venous carbon dioxide loading. A similar effect may occur after a meal when carbon dioxide production is elevated. The effects of increased carbon dioxide delivery to the lung on chemosensitivity is not known.

Elevation of body temperature is associated with increased ventilation and ventilatory responses to hypercapnia (20) and hypoxia (27). The rise in temperature which occurred after the carbohydrate meal might cause the increased minute ventilation and chemosensitivity. However, this temperature rise was inconsistent, whereas the ventilatory variables increased in all subjects. Furthermore, no such temperature change occurred after protein, although chemosensitivity and ventilation increased. It therefore seems unlikely that changes in body temperature cause the postprandial augmentation of these variables.

Carbohydrate was associated with hypermetabolism and metabolic acidosis, although no increase in the ventilatory response to carbon dioxide was found. This is surprising since both increased metabolism and metabolic acidosis (28) have been associated with augmentation of the hypercapnic response. However, exceptions have been reported. As mentioned previously, the hypermetabolic state found in Luft's syndrome was associated with increased hypoxic but not hypercapnic ventilatory response (22). Also, during renal failure where metabolic acidosis is present, no increase in hypercapnic response is found $(29,30)$.

Hamilton et al. (31) demonstrated an increase in the hypercapnic response after dialysis which lowered plasma urea, but no change when urea was held at constant concentration. They speculated that osmotic disequilibrium may increase the hypercapnic response. It is possible that a large glucose meal may have a similar effect.

Although the mechanism by which chemosensitivity is increased in the postprandial state is not clear, certain potentially useful points are raised by this study: First, the time at which ventilatory control is being measured should be standardized in relation to meals. Second, the increase in sensitivity of the ventilatory control system during a period of increased metabolism may represent an important physiologic response whereby increased demands of oxygen consumption and carbon dioxide excretion are met by increased sensitivity of the chemoreceptor system. This adjustment would protect against alteration in arterial blood gas tensions during increased metabolic activity. 


\section{ACKNOWLEDGMENTS}

We thank R. E. McCullough, Rosann Glas, and Bea Kaplan for technical assistance, and Eva Toyos and B. L. Oderberg for assistance in preparation of the manuscript.

This study was supported by National Institutes of Health Program Project grant HL 14985 and Intensive Respiratory Care and Rehabilitation grant HL 05933.

\section{REFERENCES}

1. Bhattacharya, N. K., D. Cunningham, J. C. Goode, R. C. Howson, and B. B. Lloyd. 1970. Hypoxia, ventilation, $\mathrm{PCO}_{2}$, and exercise. Respir. Physiol. 9: 329-347.

2. Weil, J. V., E. Byrne-Quinn, I. E. Sodal, J. E. Kline, R. E. McCullough, and G. F. Filley. 1972. Augmentation of chemosensitivity during mild exercise in normal man. J. Appl. Physiol. 33: 813-819.

3. Zwillich, C. W., F. D. Sutton, D. J. Pierson, and J. V. Weil. 1975. Ventilatory control in myxedema and hypothyroidism. N. Engl. J. Med. 292: 662-665.

4. Doekel, R. C., C. Zwillich, C. H. Scoggin, M. Kryger, and J. V. Weil. 1976. Clinical semi-starvation: depression of hypoxic ventilatory response. N. Engl. J. Med. 295: $358-361$.

5. Wilhelmj, C. M. 1935. The specific dynamic action of food. Physiol. Rev. 15: 202-219.

6. Saltzman, H. A., and J. V. Salzano. 1971. Effects of carbohydrate metabolism upon respiratory gas exchange in normal men. J. Appl. Physiol. 30: 228-231.

7. Weil, J. V., E. Byrne-Quinn, I. E. Sodal, W. O. Friesen, B. Underhill, F. G. Filley, and R. F. Grover. 1970. Hypoxic ventilatory drive in normal man. J. Clin. Invest. 49: 1061-1072.

8. Weil, J. V., I. E. Sodal, and R. P. Speck. 1967. A modified fuel cell for the analysis of oxygen concentration of gases. J. Appl. Physiol. 23: 419-422.

9. Dixon, W. J., and F. J. Massey, Jr. 1957. Introduction to Statistical Analysis. McGraw-Hill Book Company, New York. 112-119.

10. Read, D. J. C. 1967. A clinical method for assessing the ventilatory response to carbon dioxide. Australas. Ann. Med. 16: 20-32.

11. Hirshman, C. A., R. E. McCullough, and J. V. Weil. 1975. Normal values for hypoxic and hypercapnic ventilatory drives in man. J. Appl. Physiol. 38: 1095-1098.

12. Kronenberg, R. G., and C. W. Drage. 1973. Attenuation of the ventilatory and heart rate responses to hypoxia and hypercapnia with aging in normal man. J. Clin. Invest. 52: 1812-1819.

13. Kallos, T., H. E. Hudson, J. C. Rouge, and T. C. Smith. 1972. Interaction of the effects of naloxone and oxymorphone on human respiration. Anesthesiology. 36: 278-285.

14. Forster, H. V., J. A. Dempsey, J. Thomson, E. Vidruk, and G. A. do Pico. 1972. Estimation of arterial $\mathrm{PO}_{2}$, $\mathrm{PCO}_{2}, \mathrm{pH}$, and lactate from arterialized venous blood. $J$. Appl. Physiol. 32: 134-137.

15. Weil, J. V., G. Jamieson, D. W. Brown, and R. F. Glover. 1968. The red cell mass-arterial oxygen relationship in normal man. Application to patients with chronic obstructive airway disease. J. Clin. Invest. 47: 1627-1639.

16. Berl, T., N. Brautbar, M. M. Ben-David, W. Czaczkes, and C. Kleeman. 1976. Osmotic control of prolactin release and its effect on renal excretion in man. Kidney Int. 10: 158-163.

17. Valtin, H., and S. M. Tenney. 1960. Respiratory adaptation to hyperthyroidism. J. Appl. Physiol. 15: 1107-1112.

18. Gaudio, Jr., R., and N. Abramson. 1968. Heat-induced hyperventilation. J. Appl. Physiol. 25: 742-746.

19. Levine, S., and W. E. Huckabee. 1975. Ventilatory response to drug-induced hypermetabolism. J. Appl. Physiol. 38: 827-833.

20. Vejby-Christensen, H., and E. S. Petersen. 1973. Effect of body temperature and hypoxia on the ventilatory $\mathrm{CO}_{2}$ response in man. Respir. Physiol. 19: 322-332.

21. Engel, L. A., and B. Ritchie. 1971. Ventilatory response to inhaled carbon dioxide in hyperthyroidism. J. Appl. Physiol. 30: 173-177.

22. Edelman, N. H., T. V. Santiago, and H. L. Conn, Jr 1975. Luft's syndrome: $\mathrm{O}_{2}$ cost of exercise and chemical control of breathing. J. Appl. Physiol. 39: 857-859.

23. Biscoe, T. J., and M. J. Purves. 1967. Factors affecting the cat carotid chemoreceptor and cervical sympathetic activity with special reference to passive hind-limb movements. J. Physiol. 14: 102-104.

24. Ramsay, A. G. 1959. Effects of metabolism and anesthesia on pulmonary ventilation. J. Appl. Physiol. 14: 102-104.

25. Gabel, R. A., and R. B. Weiskopf. 1975. Ventilatory interaction between hypoxia and $\left[\mathrm{H}^{+}\right]$at chemoreceptors in man. J. Appl. Physiol. 39: 292-296.

26. Wasserman, K., B. J. Whipp, and J. Castagna. 1974. Cardiodynamic hyperpnea: hyperpnea secondary to cardiac output increase. J. Appl. Physiol. 36: 457-464.

27. Natalino, M. R., C. W. Zwillich, and J. V. Weil. 1977. Effects of hyperthermia on hypoxic ventilatory response in normal man. J. Lab. Clin. Med. 89: 564-572.

28. Heinemann, H. O., and R. M. Goldring. 1970. Bicarbonate and the regulation of ventilation. Am.J. Med. 57:361-370.

29. Anderton, J. L., E. A. Harris, and J. S. Robson. 1965. The ventilatory response to carbon dioxide and hydrogen ion in renal failure. Clin. Sci. (Oxf.). 28: 251-258.

30. Gibson, G. J., and J. A. Streeton. 1973. Ventilatory responses and acute acid-base changes in response to inhaled carbon dioxide in patients with chronic renal failure on long term hemodialysis. Respiration. 30: 389-401.

31. Hamilton, R. W., P. E. Epstein, L. W. Henderson, N. H. Edelman, and A. P. Fishman. 1976. Control of breathing in uremia: ventilatory response to $\mathrm{CO}_{2}$ after hemodialysis. J. Appl. Physiol. 41: 216-222. 